Prepared in cooperation with the Arkansas Natural Resources Commission and the Arkansas Geological Survey

\title{
Water Levels of the Ozark Aquifer in Northern Arkansas, 2013
}

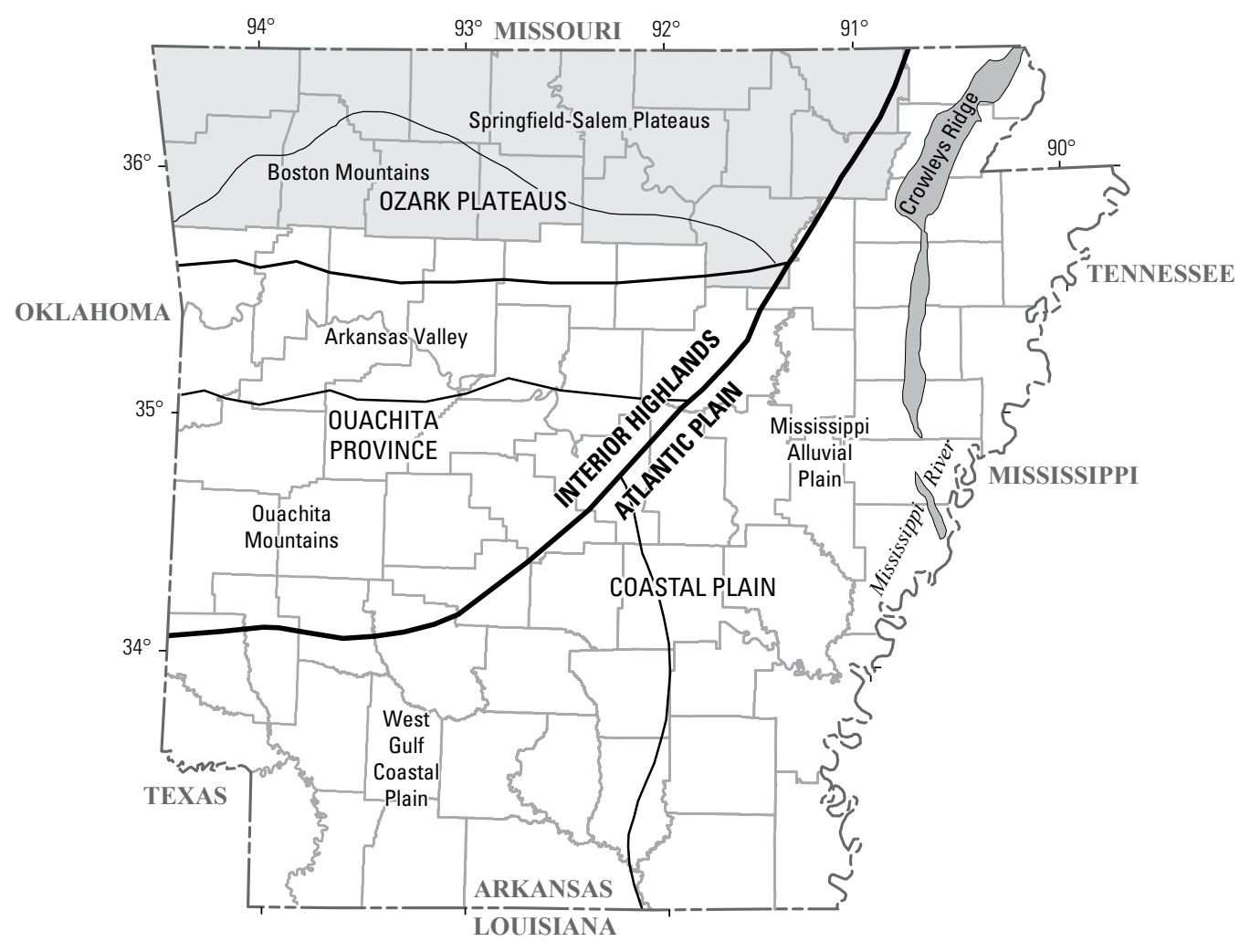

Scientific Investigations Report 2015-5088 



\section{Water Levels of the Ozark Aquifer in Northern Arkansas, 2013}

By T.P. Schrader

Prepared in cooperation with the Arkansas Natural Resources Commission and the Arkansas Geological Survey

Scientific Investigations Report 2015-5088 


\title{
U.S. Department of the Interior SALLY JEWELL, Secretary
}

\section{U.S. Geological Survey \\ Suzette M. Kimball, Acting Director}

\author{
U.S. Geological Survey, Reston, Virginia: 2015
}

For more information on the USGS - the Federal source for science about the Earth, its natural and living resources, natural hazards, and the environment—visit http://www.usgs.gov or call 1-888-ASK-USGS.

For an overview of USGS information products, including maps, imagery, and publications, visit http://www.usgs.gov/pubprod/.

Any use of trade, firm, or product names is for descriptive purposes only and does not imply endorsement by the U.S. Government.

Although this information product, for the most part, is in the public domain, it also may contain copyrighted materials as noted in the text. Permission to reproduce copyrighted items must be secured from the copyright owner.

Suggested citation:

Schrader, T.P., 2015, Water levels of the Ozark aquifer in northern Arkansas, 2013: U.S. Geological Survey Scientific Investigations Report 2015-5088, 17 p., 1 pl., http://dx.doi.org/10.3133/sir20155088.

ISSN 2328-0328 (online) 


\section{Contents}

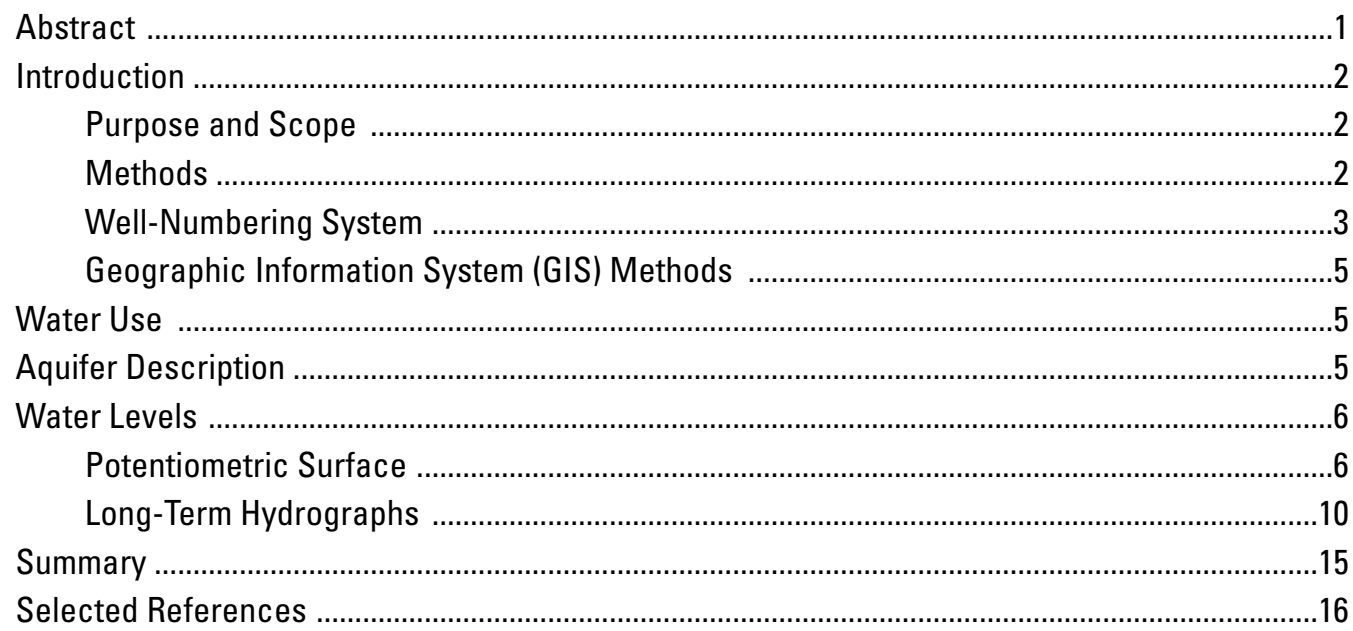

\section{Plate}

1. Map showing potentiometric surface for the Ozark aquifer in northern Arkansas, 2013

\section{Figures}

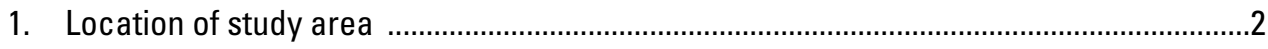

2. Location of Ozark Plateaus aquifer system ....................................................................

3. Diagram showing well numbering system ...................................................................

4. Water use for Ozark aquifer in northern Arkansas, 1965-2010 ..........................................5

5. Water-level hydrographs for selected wells completed in the Ozark aquifer in

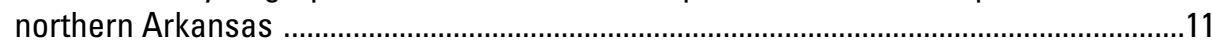

\section{Tables}

1. Stratigraphic column with descriptions of lithologic and hydrogeologic properties of the Ozark aquifer and adjacent confining units within Arkansas 7

2. Information pertaining to measured wells and springs in the Ozark aquifer in northern Arkansas, 2013 


\section{Conversion Factors}

Inch/Pound to SI

\begin{tabular}{lcl}
\hline \multicolumn{1}{c}{ Multiply } & By & \multicolumn{1}{c}{ To obtain } \\
\hline foot (ft) & Length & meter $(\mathrm{m})$ \\
mile (mi) & 0.3048 & kilometer $(\mathrm{km})$ \\
\hline & 1.609 & \\
\hline foot per second $(\mathrm{ft} / \mathrm{s})$ & Flow rate & meter per second $(\mathrm{m} / \mathrm{s})$ \\
foot per year $(\mathrm{ft} / \mathrm{yr})$ & 0.3048 & meter per year $(\mathrm{m} / \mathrm{yr})$ \\
gallon per minute $(\mathrm{gal} / \mathrm{min})$ & 0.3048 & liter per second $(\mathrm{L} / \mathrm{s})$ \\
million gallons per day $(\mathrm{Mgal} / \mathrm{d})$ & 0.06309 & cubic meter per second $\left(\mathrm{m}^{3} / \mathrm{s}\right)$ \\
\hline
\end{tabular}

\section{Datum}

Horizontal coordinate information is referenced to the North American Datum of 1983 (NAD 83).

Vertical coordinate information is referenced to the National Geodetic Vertical Datum of 1929 (NGVD 29).

Altitude, as used in this report, refers to distance above the vertical datum. 


\title{
Water Levels of the Ozark Aquifer in Northern Arkansas, 2013
}

\author{
By T.P. Schrader
}

\section{Abstract}

The Ozark aquifer is the largest aquifer, both in area of outcrop and thickness, and the most important source of freshwater in the Ozark Plateaus physiographic province, supplying water to northern Arkansas, southeastern Kansas, southern Missouri, and northeastern Oklahoma. The study area includes 16 Arkansas counties lying completely or partially within the Ozark Plateaus of the Interior Highlands major physiographic division. The U.S. Geological Survey, in cooperation with the Arkansas Natural Resources Commission and the Arkansas Geological Survey, conducted a study of water levels in the Ozark aquifer within Arkansas. This report presents a potentiometric-surface map of the Ozark aquifer within the Ozark Plateaus of northern Arkansas, representing water-level conditions for the early spring of 2013 and selected water-level hydrographs.

The Ozark aquifer in Arkansas is composed of dolomites, limestones, sandstones, and shales of Late Cambrian to Middle Devonian age and ranges in thickness from approximately 1,100 feet (ft) in northwestern Arkansas to more than 4,000 ft in the west-central part of Arkansas. Most wells completed in the aquifer yield between 50 and 100 gallons per minute (gal/min), although some wells may yield as much as $600 \mathrm{gal} / \mathrm{min}$.

Water-level measurements were made in wells completed in the Ozark aquifer from February to May 2013. Hydrographs were constructed for nine wells that have water-level measurements with a minimum 20-year period of record.

Water-level altitudes in wells used to construct the potentiometric-surface map range from about $1,159 \mathrm{ft}$ to $313 \mathrm{ft}$ above National Geodetic Vertical Datum of 1929 (NGVD 29). The highest water-level altitudes occur in Carroll and Washington Counties while water-level altitudes of less than $400 \mathrm{ft}$ above NGVD 29 are mapped along the eastern and southeastern part of the study area in Independence, Lawrence, Randolph, and Sharp Counties. The lowest water level of $313 \mathrm{ft}$ above NGVD 29 was measured in southwestern Randolph County.

The direction of groundwater flow generally is affected by local topography, flowing from high altitudes toward stream valleys. In southern Baxter, eastern Fulton, Independence, eastern Izard, Lawrence, Randolph, and Sharp Counties, the groundwater flow is generally to the south and southeast. In western Fulton and Izard Counties, the groundwater flow is generally to the southwest. In Boone, Marion, Newton, Searcy, and Stone Counties, the groundwater flow is generally to the east and northeast. In eastern Benton, Carroll, Madison, and eastern Washington Counties, the groundwater flow is generally to the north and northeast. In western Benton and western Washington Counties, the groundwater flow is generally to the west and northwest.

The general level and shape of the potentiometric surface has changed little since predevelopment. A comparison of the predevelopment potentiometric surface and the 2007 , 2010 , and 2013 potentiometric surfaces indicate general agreement between the mapped surfaces with the exception of parts of Benton, Boone, Marion, and Washington Counties. In Boone and northern Marion Counties in 2013, water levels have declined when compared to the predevelopment potentiometric surface, although the direction of flow is still to the northeast and north. In southern Marion County, water levels have declined when compared to the predevelopment, 2007, and 2010 potentiometric surfaces, although the direction of flow is towards and along the stream valleys. In western Benton and northwestern Washington Counties, water levels are similar when compared to the predevelopment potentiometric surface, and the direction of flow is to the west and northwest, similar to the predevelopment direction of flow. The mapped 2007 and 2010 potentiometric surfaces are very different from the mapped 2013 potentiometric surface in western Benton and northwestern Washington Counties. The mapped 2013 potentiometric surface in western Benton and northwestern Washington Counties follows the contours of the top of the formation, similar to the predevelopment potentiometric surface. Since 1975, water use in the Ozark aquifer has declined 45 percent, while water levels in Benton, Boone, Marion, and Washington Counties continue to decline.

Nine hydrographs were selected as representative of the water-level conditions in their respective counties. Wells in Fulton, Izard, and Newton Counties (station names 20N08W27ABD1, 18N09W15BCB1, and 16N21W34ABC1, respectively) have water levels that are within the usual range of values for their respective counties. Wells in Boone, Marion, and Washington Counties (station names 18N19W19BCC1, 19N15W20ACC1, and 16N32W09ABD1, respectively) have water levels that have recently declined or are declining for the period of record. Wells in Benton, 
Carroll, and Sharp Counties (station names 19N29W07DAA1, 21N26W17BCC1, and 15N05W06DDD1, respectively) have water levels that have been rising recently.

\section{Introduction}

The Ozark aquifer is the largest aquifer, both in area of outcrop and thickness, and the most important source of freshwater in the Ozark Plateaus physiographic province, supplying water to northern Arkansas, southeastern Kansas, southern Missouri, and northeastern Oklahoma. An understanding of the changes and trends in water levels is important for the continued use, planning, and management of this important natural resource (Imes and Emmett, 1994).

The U.S. Geological Survey (USGS), in cooperation with the Arkansas Natural Resources Commission and the Arkansas Geological Survey, conducted a study of water levels in the Ozark aquifer within Arkansas. The study is part of an ongoing effort to monitor groundwater levels in Arkansas' major aquifers. The study area includes 16 Arkansas counties lying completely or partially within the Ozark Plateaus of the Interior Highlands major physiographic division (Fenneman and Johnson, 1946). The study area generally is bounded on the north by Missouri, on the west by Oklahoma, on the east by the Mississippi Alluvial Plain, and on the south by the Ouachita Province (fig. 1).

\section{Purpose and Scope}

This report presents a potentiometric-surface map of the Ozark aquifer within the Ozark Plateaus of northern Arkansas (figs. 1 and 2) and selected water-level hydrographs. The potentiometric-surface map was prepared from data collected by the USGS during spring 2013 from wells located in and springs flowing from the Ozark aquifer. An understanding of changes and trends in water levels is important for the continued use, planning, and management of this resource.

\section{Methods}

Water levels were measured in spring 2013 from wells completed in the Ozark aquifer. Measurements were made by USGS personnel using steel or electric tapes graduated in hundredths of a foot. Water levels were collected according to USGS procedural documentation (Cunningham and Schalk, 2011). The steel and electric tapes were calibrated

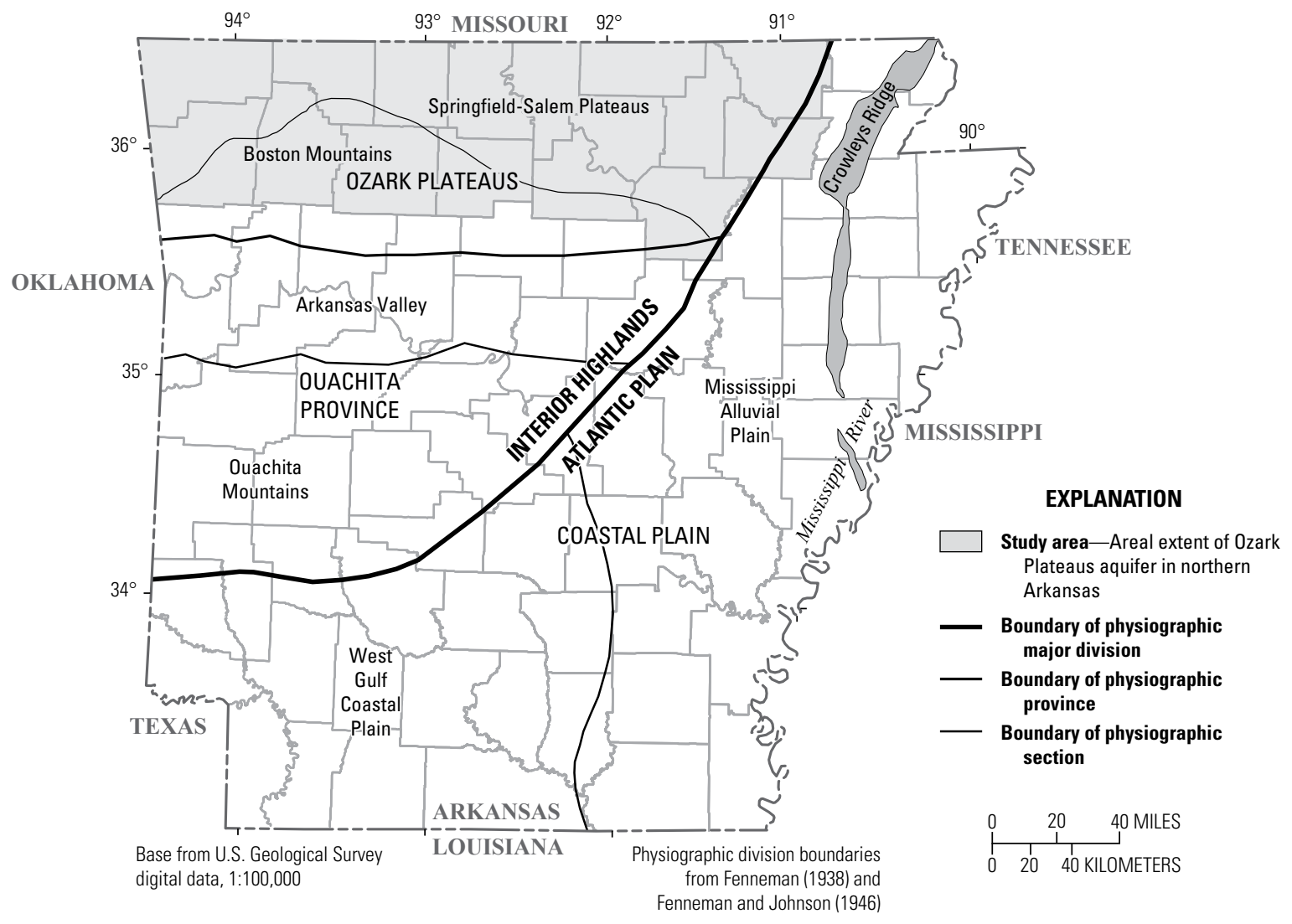

Figure 1. Location of study area. 


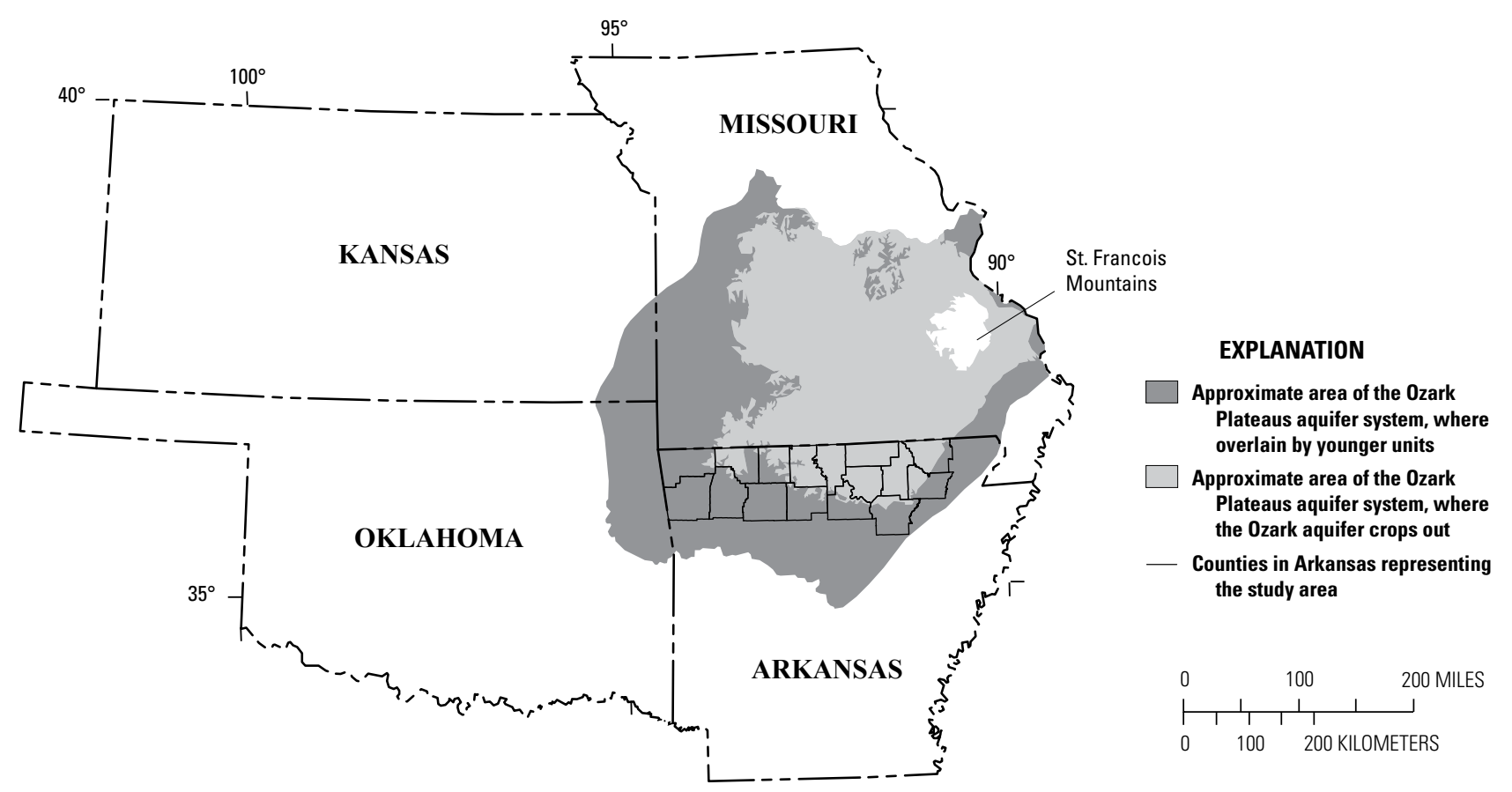

Figure 2. Location of Ozark Plateaus aquifer system.

prior to collecting water-level measurements. Calibration was performed by comparing the steel or electric tapes to a standardized steel tape used only for calibration. Tape calibrations are performed annually.

Well locations were verified using Global Positioning System (GPS) receivers to acquire the horizontal-coordinate information and latitude and longitude, based on the North American Datum of 1983. The latitude and longitude of the wells were recorded from a GPS receiver accurate to onetenth of a second of latitude and longitude (approximately 10-20 feet [ft]). The latitude and longitude of each well were transferred to USGS 1:24,000 topographic maps, and the altitude of each well was determined from the topographic contours at the location on the map (National Geodetic Vertical Datum of 1929 [NGVD 29]). Altitude is accurate from about 2.5 to $10 \mathrm{ft}$, or half the contour interval on the map. Streambed altitudes in areas where the aquifer is unconfined (outcrop of the Ozark aquifer, fig. 2) and hydraulically connected to the surface were used as control point (maximum groundwater level) values. Control point latitudes, longitudes, and values were determined from USGS 1:24,000 topographic maps and transferred to the potentiometric-surface map, plate 1 .

Contours in the outcrop area, where the Ozark aquifer is unconfined, were drawn using water-level altitudes from wells and springs, control points from stream altitudes, and the altitude of the land surface. The land surface in the outcrop area is the top of the formation and is the upper limit for water-level altitudes. The control points from stream altitudes prevent contours from crossing streams at inappropriate locations and to reflect the general land-surface topography where appropriate (Czarnecki and others, 2014). Contours outside the outcrop area, where the Ozark aquifer is confined, were drawn using water-level altitudes from wells. The waterlevel altitudes are similar to altitudes for the predevelopment potentiometric surface and the top of the formation (Imes, 1990). The water-level altitudes, predevelopment potentiometric surface, and the top of the formation were used to draw the contours outside the outcrop area.

\section{Well-Numbering System}

The well-numbering system used in this report is based upon the Public Land Survey System (White, 1983) used in Arkansas (fig. 3). The component parts of a well number are the township designation; the range designation; the section number; three-letter designation that indicates, respectively, the quarter section, the quarter-quarter section, and the quarter-quarter-quarter section in which the well is located; and the sequence number of the well in the quarter-quarterquarter section. The letters are assigned counterclockwise, beginning with " $\mathrm{A}$ " in the northeast quarter or quarter-quarter or quarter-quarter-quarter section in which the well is located. For example, well 01S03W04BBD16 (fig. 3) is located in Township 1 South, Range 3 West, in the southeast quarter of the northwest quarter of the northwest quarter of section 4 . This well is the 16th well in this quarter-quarter-quarter section of section 4 from which data were collected. 


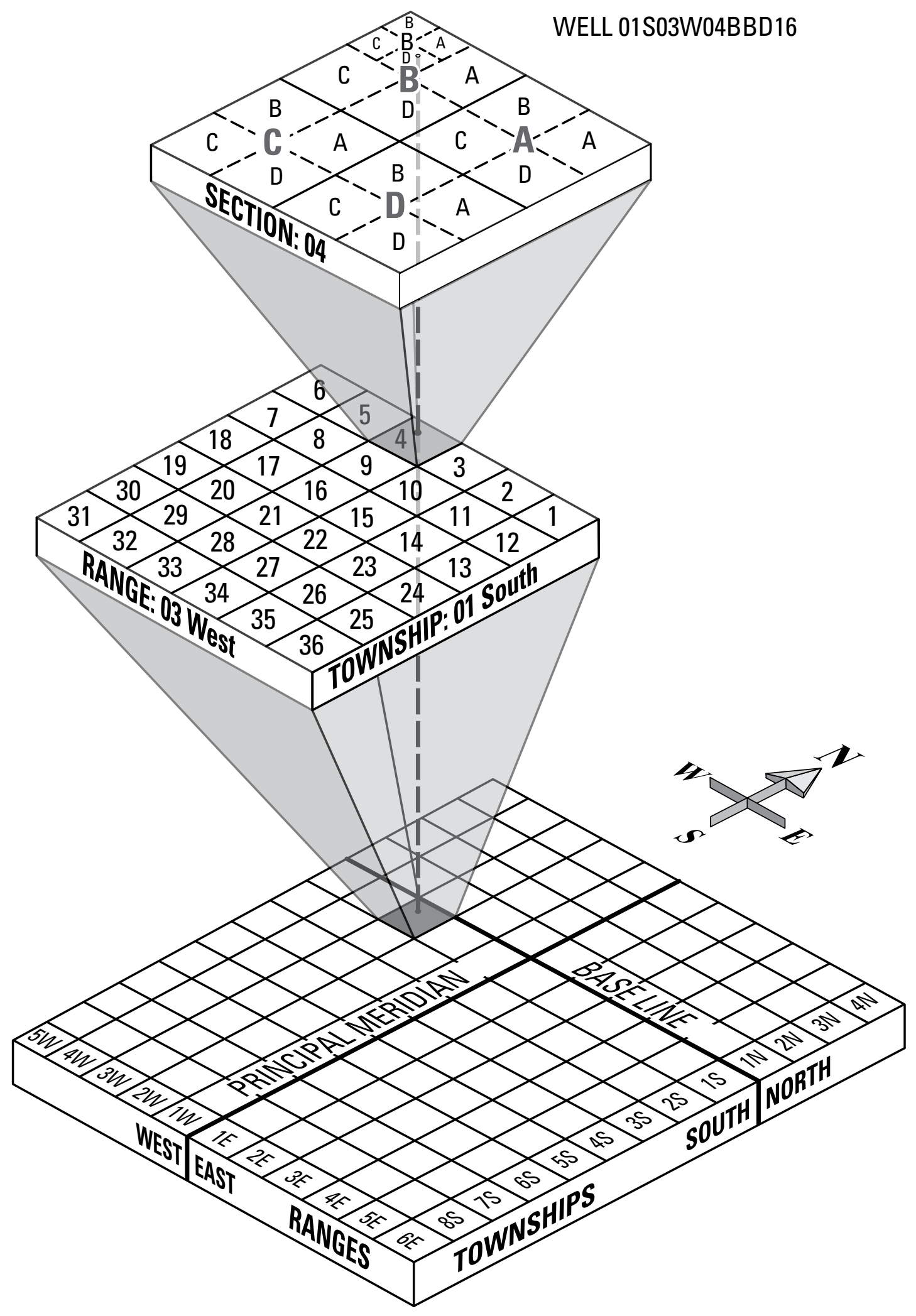

Figure 3. Diagram showing well numbering system. 


\section{Geographic Information System (GIS) Methods}

Latitude and longitude of wells and springs were retrieved from the USGS National Water Information System (NWIS) (http://waterdata.usgs.gov/nwis) and plotted using ArcGIS (http://www.esri.com/). The coordinates of springs, wells, control points, and the measured water levels were used to construct the potentiometric map of the Ozark aquifer. Initial construction of the potentiometric surface was drafted manually. Contours were then georeferenced into ArcGIS where subsequent manual adjustments were finalized. A digital image of the map and potentiometric surface can be downloaded from http://pubs.usgs.gov/sir/2015/5088/.

\section{Water Use}

Water use from the Ozark aquifer in Arkansas was estimated to be 21.2 million gallons per day (Mgal/d) in 2010 (fig. 4) (Terrance W. Holland, U.S. Geological Survey, written commun., 2013). Water use increased about 168 percent from 1965 to 1975 , then decreased about 45 percent from 1975 to 2010. Water use from the Ozark aquifer declined when some public suppliers converted from a groundwater to a surface-water source and some domestic users connected to a surface-water source for public supplies (Terrance W. Holland, U.S. Geological Survey, written commun., 2013).

\section{Aquifer Description}

The Ozark Plateaus aquifer system (fig. 2) is in, and adjacent to, the Ozark Plateaus and may be divided into five hydrogeologic units based on relative rock permeability and well yields. These units crop out in a concentric pattern centered on and dipping away from the St. Francois Mountains of Missouri. The boundaries between these hydrologic units do not always conform to geologic time divisions or formation boundaries but were chosen to delineate groups of rocks having similar hydrologic properties. These geohydrologic units consist of rocks that range in age from Cambrian to Mississippian and are the St. Francois aquifer, St. Francois confining unit, Ozark aquifer, Ozark confining unit, and Springfield aquifer (Imes and Emmett, 1994). The St. Francois aquifer and St. Francois confining unit underlie the Ozark aquifer. The Ozark confining unit overlies the Ozark aquifer. The Springfield aquifer overlies the Ozark confining unit.

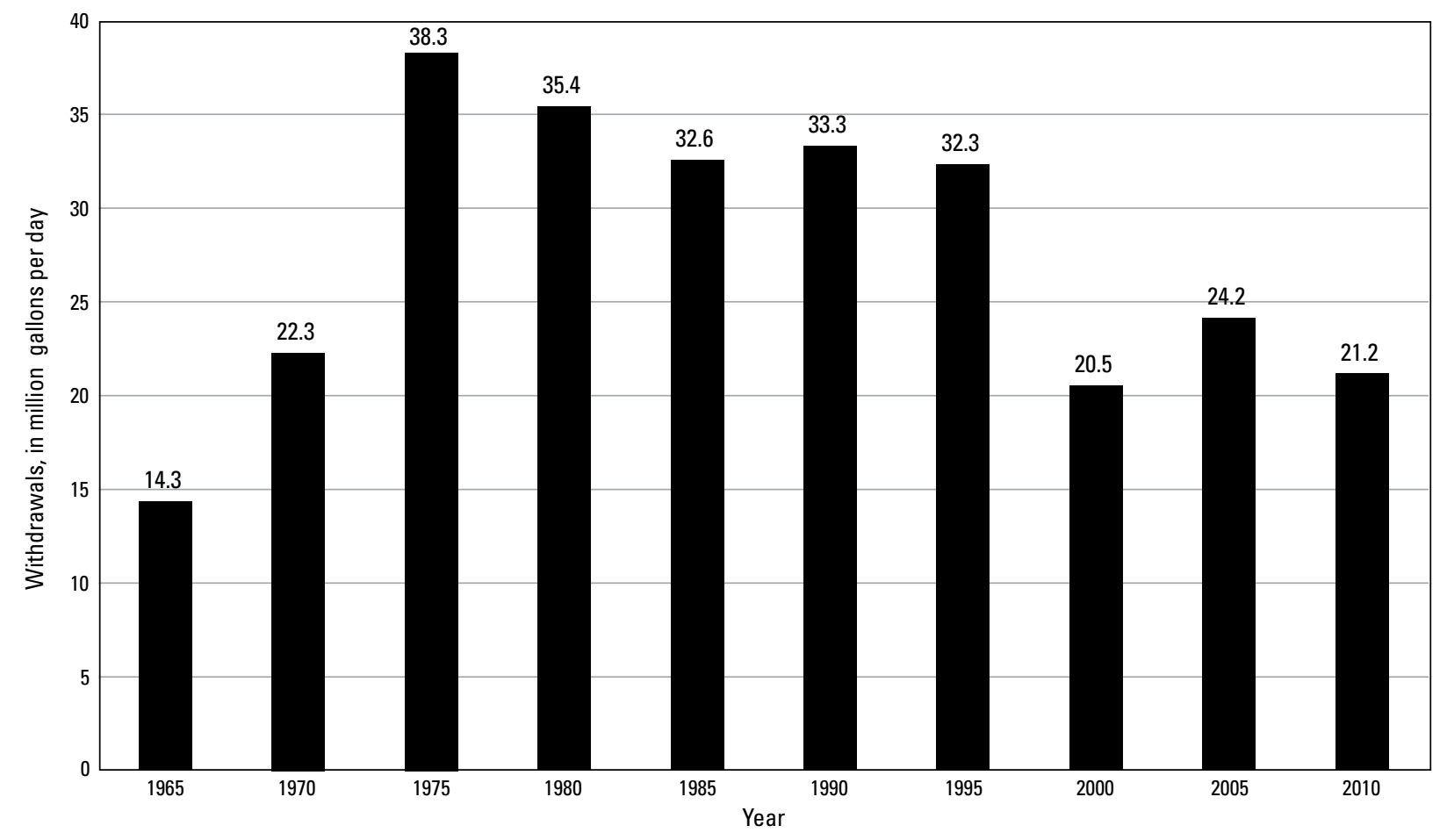

Data compiled from Halberg (1972, 1977); Halberg and Stephens (1966); Holland, (1987, 1993, 1999, 2004, 2007); Holland and Ludwig (1981); and Terrance W. Holland, U.S. Geological Survey, written commun., 2013

Figure 4. Water use for Ozark aquifer in northern Arkansas, 1965-2010. 
The Ozark aquifer in Arkansas is composed of dolomites, limestones, sandstones, and shales of Late Cambrian to Middle Devonian age (table 1) and ranges in thickness from approximately $1,100 \mathrm{ft}$ in the northwestern corner of Arkansas to more than 4,000 ft in the west-central part of Arkansas (Imes, 1990). Most wells completed in the aquifer yield between 50 and 100 gallons per minute (gal $/ \mathrm{min})$, although some wells may yield as much as $600 \mathrm{gal} / \mathrm{min}$ (Imes and Emmett, 1994; Adamski and others, 1995).

The geohydrology of the Ozark aquifer is complex, consisting of a combination of discrete and discontinuous flow components resulting from spatial variations in regolith thickness, faults, and the presence of chert nodules, lithology, and cementation. Primary porosity and permeability are low for most rock units of the aquifer, although secondary permeability resulting from fracturing and dissolution of the carbonate rocks is spatially variable and ranges from moderate to large. Karst topography in the Ozark aquifer consists primarily of limestone and dolomite rocks, which have been dissolved, in places, by groundwater to form caves, sinkholes, and springs. These dissolution features allow rapid recharge to the aquifer (Adamski, 1996).

Hydraulic conductivity ranges from $1 \times 10^{-8}$ feet per second $(\mathrm{ft} / \mathrm{s})$ to more than $1 \times 10^{-3} \mathrm{ft} / \mathrm{s}$. The principal recharge area for the aquifer is in central and south-central Missouri and northcentral Arkansas. In this area, the aquifer is hydraulically connected to the surface, and the potentiometric surface mimics the land-surface topography (Imes and Emmett, 1994).

The Ozark aquifer is underlain by the St. Francois confining unit (the top geologic unit of which is the Doe Run Dolomite; table 1). The Ozark aquifer is exposed in much of southern and central Missouri and north-central Arkansas (fig. 2) where uplift of the Ozark dome and erosion of younger rocks have formed a deeply dissected rugged topography that is the primary recharge area of the aquifer. The aquifer is overlain by the Ozark confining unit (table 1) mainly in the southern and western part of the study area. Within the Mississippi Alluvial Plain, east and southeast of the outcrop area (figs. 1 and 2), thick deposits of Cretaceous-, Tertiary-, and Quaternary-age sediments unconformably overlay the Ordovician-age rocks of the Ozark aquifer. Within this part of the Mississippi Alluvial Plain, major streams receive substantial discharge from the adjacent Ozark aquifer (Mesko and Imes, 1995).

Beneath the Mississippi Alluvial Plain (fig. 1), the rocks comprising the Ozark aquifer dip at about 45 feet per mile ( $\mathrm{ft} / \mathrm{mi}$ ) to the southeast. In the northern part of the study area, the regional dip is about $26 \mathrm{ft} / \mathrm{mi}$ southward, increasing to $175 \mathrm{ft} / \mathrm{mi}$ or more at the southern boundary of the Ozark Plateaus (Imes, 1990). The depth of the Ozark aquifer increases to more than $2,000 \mathrm{ft}$ in the southern part of the study area. In this area, water quality is affected by increasing amounts of dissolved solids, fluoride, sulfide, and radium as water moves downdip, away from recharge areas (Imes and Emmett, 1994). The combination of greater depth and poorer water quality limits the viability of the Ozark aquifer as an economic source of water in the southernmost part of the study area.

\section{Water Levels}

Water-level measurements were made in wells completed in the Ozark aquifer (table 1) from February to May 2013. The potentiometric-surface map (pl. 1) was contoured and hydrographs were constructed using the water-level data from 42 wells and 6 springs (table 2). Hydrographs were constructed for nine wells with a minimum 20 -year period of record (fig. 5). The water levels shown in the hydrographs indicate long-term changes in hydrologic conditions. Long-term water-level declines reflect the response of the groundwater-flow system to stresses caused by groundwater pumping or variations in climate (fig. 5).

The Ozark aquifer covers a large area in Arkansas and has variable thickness and hydrologic properties. Data point distribution is sparse in some areas. The potentiometricsurface map is intended to show the general configuration of the potentiometric surface and should not be used to estimate exact water-level altitude or depth to water at any given location.

\section{Potentiometric Surface}

The extent of the potentiometric-surface map (pl. 1) covers approximately half of the defined study area. The Ozark aquifer in the southern part of the study area is not a viable source of water because of the great depths and poor water quality; therefore, few wells have been constructed in that area, and data are not available for contouring purposes.

Water-level altitudes in wells used to construct the potentiometric-surface map range from about $1,159 \mathrm{ft}$ to $313 \mathrm{ft}$ above NGVD 29. The highest measured water-level altitudes occur in Carroll and Washington Counties. The water-level altitudes in this area are reflective of the influence of the local land-surface topography and not the regional flow pattern of the aquifer. Water-level altitudes of less than $400 \mathrm{ft}$ above NGVD 29 are mapped along the eastern and southeastern part of the study area in Independence, Lawrence, Randolph, and Sharp Counties. The lowest water level of $313 \mathrm{ft}$ above NGVD 29 was measured in southwestern Randolph County.

The direction of groundwater flow generally is affected by local topography in the outcrop area, flowing from high altitudes toward stream valleys. Groundwater flow is perpendicular to the potentiometric contours (pl. 1) in the direction of hydraulic gradient. In southern Baxter, eastern Fulton, Independence, eastern Izard, Lawrence, Randolph, and Sharp Counties, the groundwater flow is generally to the south and southeast. In western Fulton and Izard Counties, the groundwater flow is generally to the southwest. In Boone, Marion, Newton, Searcy, and Stone Counties, the groundwater flow is generally to the east and northeast. In eastern Benton, Carroll, Madison, and eastern Washington Counties, the groundwater flow is generally to the north and northeast. In western Benton and western Washington Counties, the groundwater flow is generally to the west and northwest. 
Table 1. Stratigraphic column with descriptions of lithologic and hydrogeologic properties of the Ozark aquifer and adjacent confining units within Arkansas (modified from Lamonds, 1972; Imes, 1990; Imes and Smith, 1990).

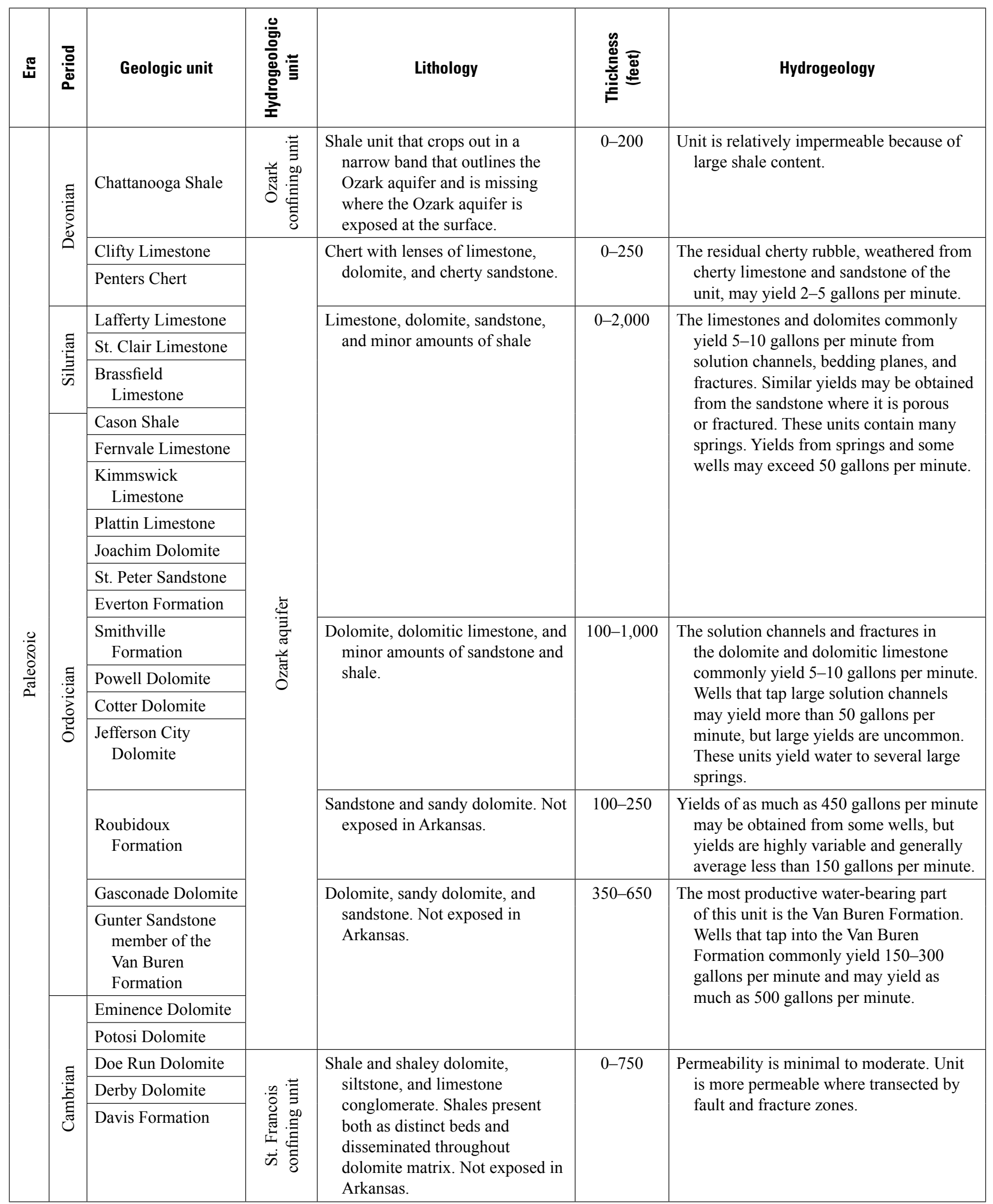




\section{Water Levels of the Ozark Aquifer in Northern Arkansas, 2013}

Table 2. Information pertaining to measured wells and springs in the Ozark aquifer in northern Arkansas, 2013.

[NGVD 29, National Geodetic Vertical Datum of 1929; Horizontal coordinate information is referenced to the North American Datum of 1983 (NAD 83 ); NA, not applicable,--, not available; Aquifer code designations are: 361FRVL Fernvale Limestone: 364STPR, St. Peter Sandstone; 364EVRN, Everton Formation; 368PWLL, Powell Dolomite; 367CTTR, Cotter Dolomite; 368JFRC, Jefferson City Dolomite; 367RBDX, Roubidoux Formation, 367GNTR, Gunter Sandstone member of the Van Buren Formation; 371POTS, Potosi Dolomite]

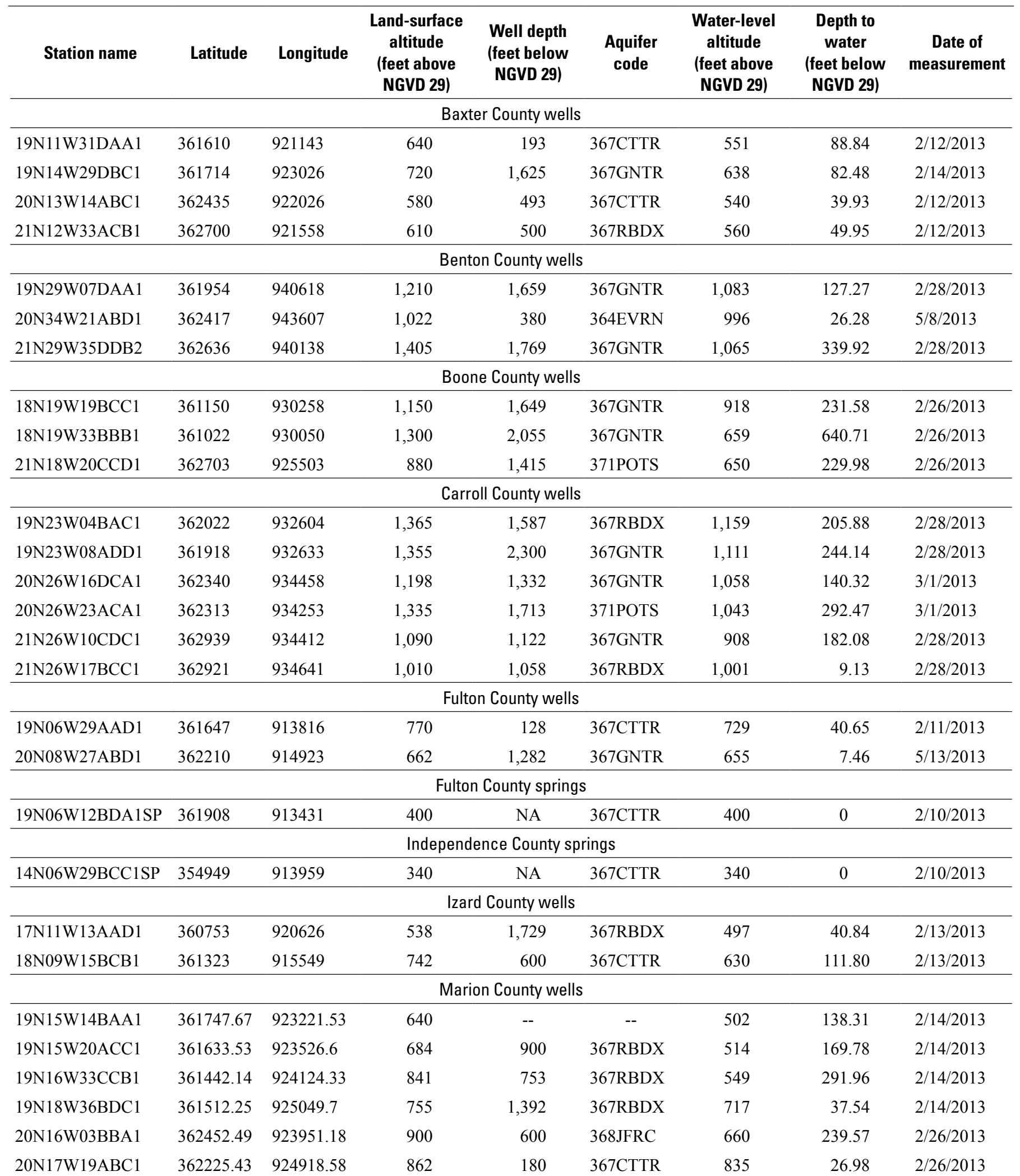


Table 2. Information pertaining to measured wells and springs in the Ozark aquifer in northern Arkansas, 2013.—Continued

[NGVD 29, National Geodetic Vertical Datum of 1929; Horizontal coordinate information is referenced to the North American Datum of 1983 (NAD 83); NA, not applicable,--, not available; Aquifer code designations are: 361FRVL Fernvale Limestone: 364STPR, St. Peter Sandstone; 364EVRN, Everton Formation; 368PWLL, Powell Dolomite; 367CTTR, Cotter Dolomite; 368JFRC, Jefferson City Dolomite; 367RBDX, Roubidoux Formation, 367GNTR, Gunter Sandstone member of the Van Buren Formation; 371POTS, Potosi Dolomite]

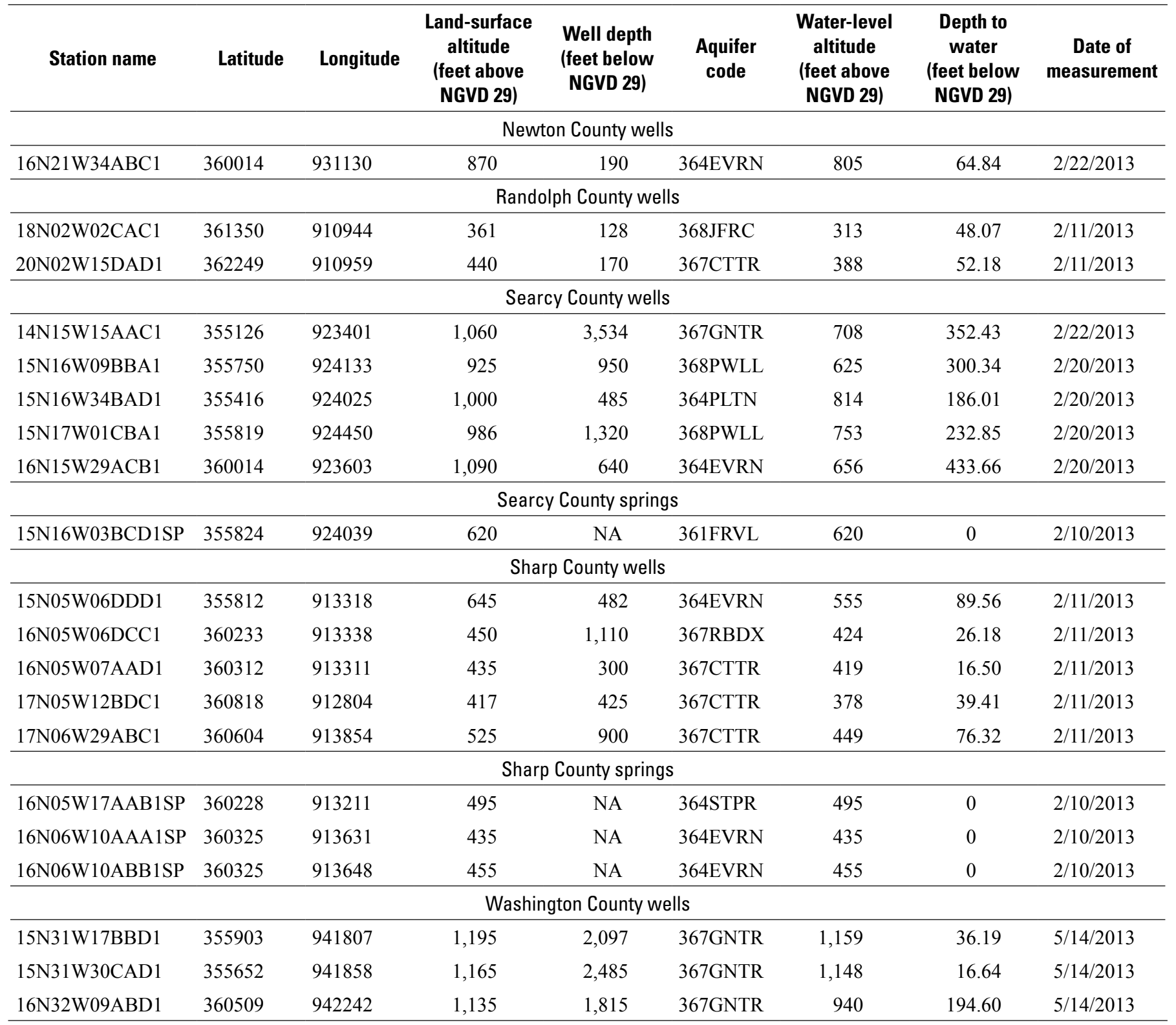


In most of the study area, the general altitude and shape of the potentiometric surface of the Ozark aquifer has changed little since predevelopment or as was mapped in previously published USGS reports (Pugh, 1998, 2008; Schrader, 2001, 2005; Czarnecki and others, 2014). A comparison of the predevelopment potentiometric surface (Imes, 1990) and the 2007, 2010, and 2013 potentiometric surfaces indicates a general agreement between the mapped surfaces with the exception of parts of Benton, Boone, Marion, and Washington Counties. In Boone and northern Marion Counties in 2013, water levels have declined when compared to the predevelopment potentiometric surface, although the direction of flow is still to the northeast and north. In southern Marion County, water levels have declined when compared to the predevelopment, 2007, and 2010 potentiometric surfaces, although the direction of flow is towards and along the stream valleys. The 2007 and 2010 potentiometric surfaces are in agreement with the 2013 potentiometric surface in Boone and northern Marion Counties. In western Benton and northwestern Washington Counties, water levels are similar when compared to the predevelopment potentiometric surface and the direction of flow is to the west and northwest, similar to the predevelopment direction of flow. The mapped 2007 and 2010 potentiometric surfaces are very different from the mapped 2013 potentiometric surface in western Benton and northwestern Washington Counties. Much of this apparent difference could be because of differences in hydrologic interpretation. Water-level data are sparse in central Benton and southwestern and eastern Washington Counties, interpretations of potentiometric surfaces are dependent on the top of the formation (Imes, 1990). The mapped 2013 potentiometric surface in western Benton and northwestern Washington Counties generally follows the contours of the top of the formation, similar to the predevelopment potentiometric surface (Imes, 1990).

Since 1975, water use in the Ozark aquifer has declined 45 percent, while water levels in Benton, Boone, Marion, and Washington Counties continue to decline. Localized pumping or other external factors may affect water levels in these areas. Potentiometric-surface differences from previous maps can be attributed to changes in hydrologic stresses (withdrawals related to changing population, changes in withdrawals for agricultural uses, or withdrawal conditions just prior to a water-level measurement) or data-collection and map-construction methods (time of year or the number and locations of water-level measurements used to construct maps representing different years).

\section{Long-Term Hydrographs}

Hydrographs were constructed for wells with a minimum 20-year period of record; 22 of the 42 wells fit this description. Nine hydrographs (fig. 5) were selected as representative of the water-level conditions in their respective counties. Wells in Fulton, Izard, and Newton Counties (station names 20N08W27ABD1 [fig. 5D, pl. 1], 18N09W15BCB1 [fig. 5E, pl. 1], and16N21W34ABC1 [fig. 5G, pl. 1], respectively) have water levels that are within the range of values for their respective counties. Water levels in the well in Fulton County generally rose from 1975 to 1985 and then fluctuated within a range of about $20 \mathrm{ft}$ from 1985 to 2013. Water levels in the well in Izard County fluctuated within a range of about $85 \mathrm{ft}$ from 1965 to 2013. Water levels in the well in Newton County fluctuated within a range of about $11 \mathrm{ft}$ from 1965 to 2013.

Water levels in the wells in Boone, Marion, and Washington Counties (station names 18N19W19BCC1 [fig. $5 B$, pl. 1], 19N15W20ACC1 [fig. $5 F$, pl. 1], and16N32W09ABD1 [fig. 5I, pl. 1], respectively) have water levels that have recently declined or are declining for the period of record. Water levels in the wells in Boone and Washington Counties have a general decline throughout the period of record. Water levels in the well in Marion County have been variable, fluctuating within about a $22-\mathrm{ft}$ range from 1966 to 1995 . Water levels declined from 1995 to 2001, rose from 2001 to 2007, and declined from 2007 to 2013. These fluctuating water levels could be the result of variations in pumping or climate through time.

Water levels in the wells in Benton, Carroll, and Sharp Counties, (station names 19N29W07DAA1 [fig. 5A, pl. 1], 21N26W17BCC1 [fig. 5C, pl. 1], and 15N05W06DDD1 [fig. $5 H$, pl. 1], respectively) have water levels that have been rising. Water levels in the well in Benton County rose from 1965 to 1975 , declined from 1975 to 1995 , and generally rose from 1995 to 2013. Water levels in the well in Carroll County were variable from 1970 to 1995 and have risen about $100 \mathrm{ft}$ from 1995 to 2013. Water levels in the well in Sharp County generally declined from 1966 to 1978 and generally rose from 1978 to 1985 and have fluctuated within a range of about $20 \mathrm{ft}$ from 1985 to 2010 . The water level rose about $17 \mathrm{ft}$ from 2010 to 2013 . 


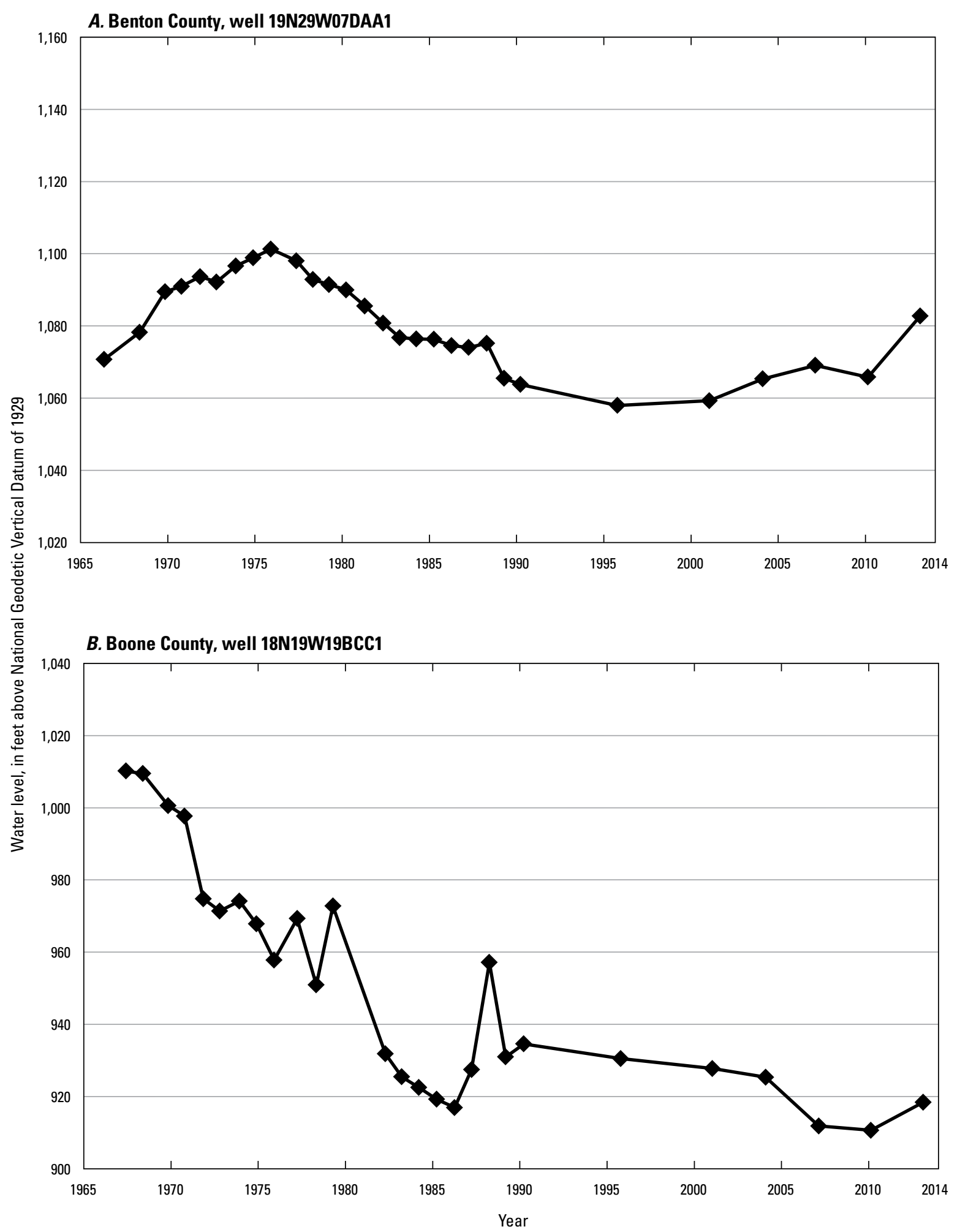

Figure 5. Water-level hydrographs for selected wells completed in the Ozark aquifer in northern Arkansas. 


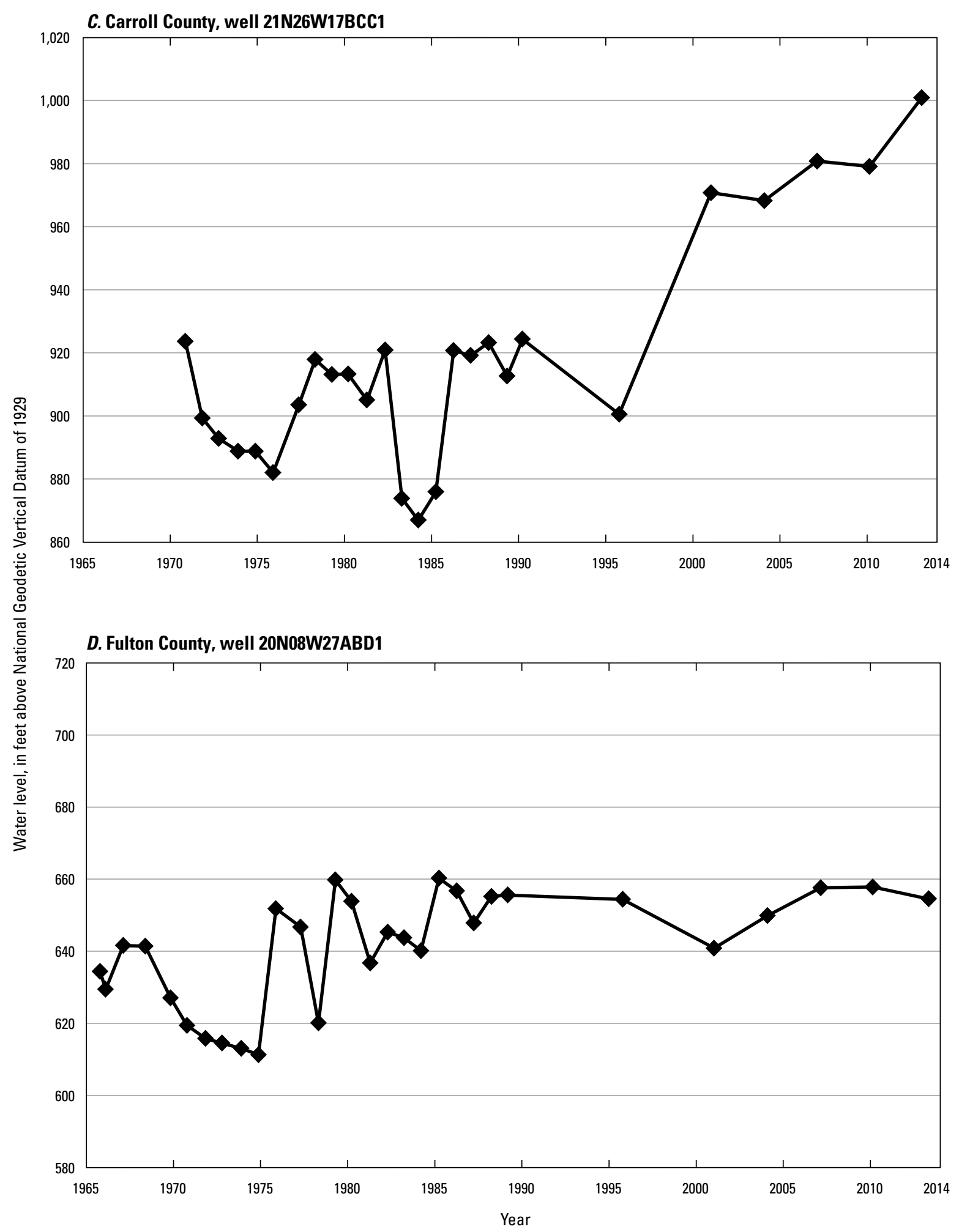

Figure 5. Water-level hydrographs for selected wells completed in the Ozark aquifer in northern Arkansas.-Continued 


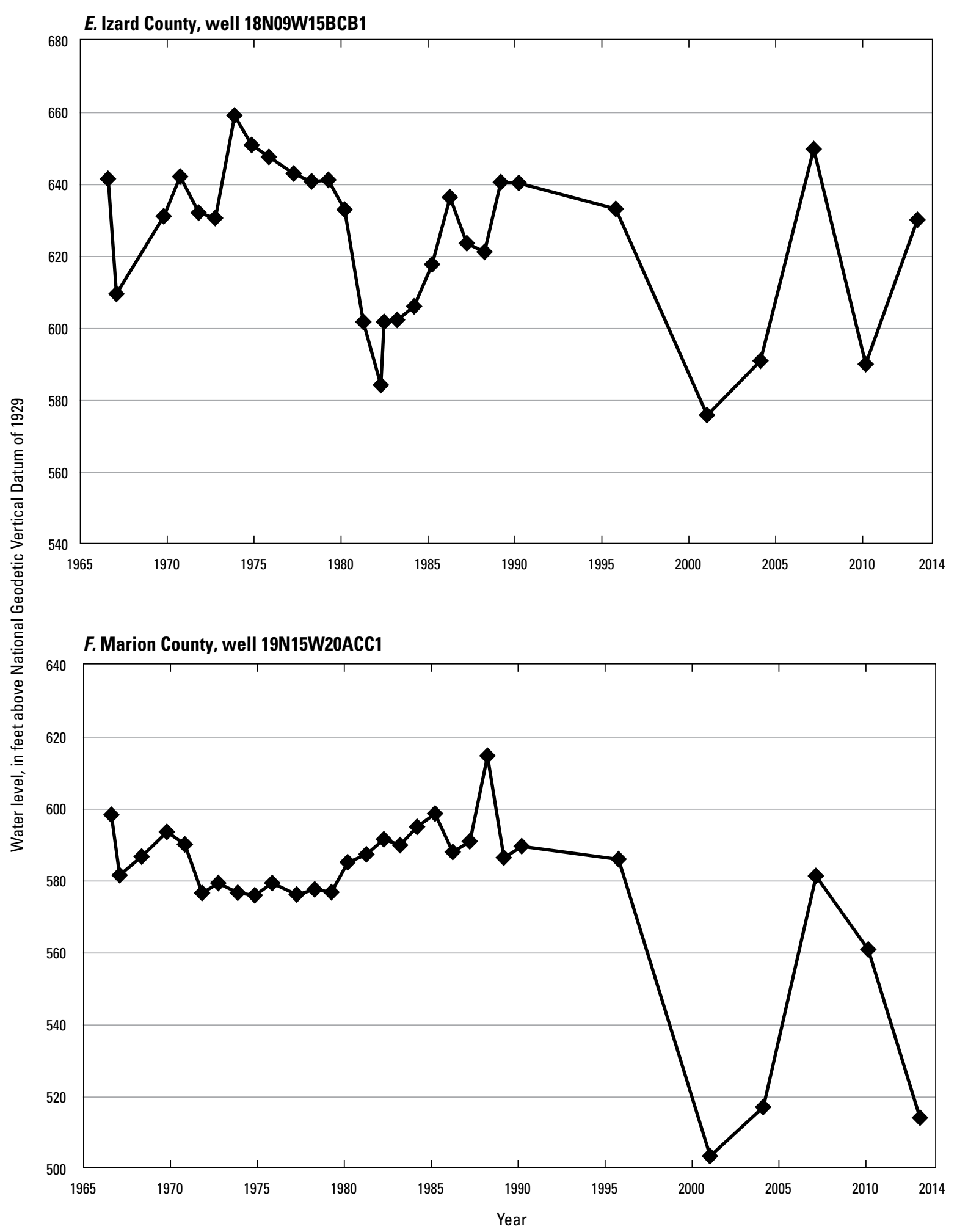

Figure 5. Water-level hydrographs for selected wells completed in the Ozark aquifer in northern Arkansas.—Continued 

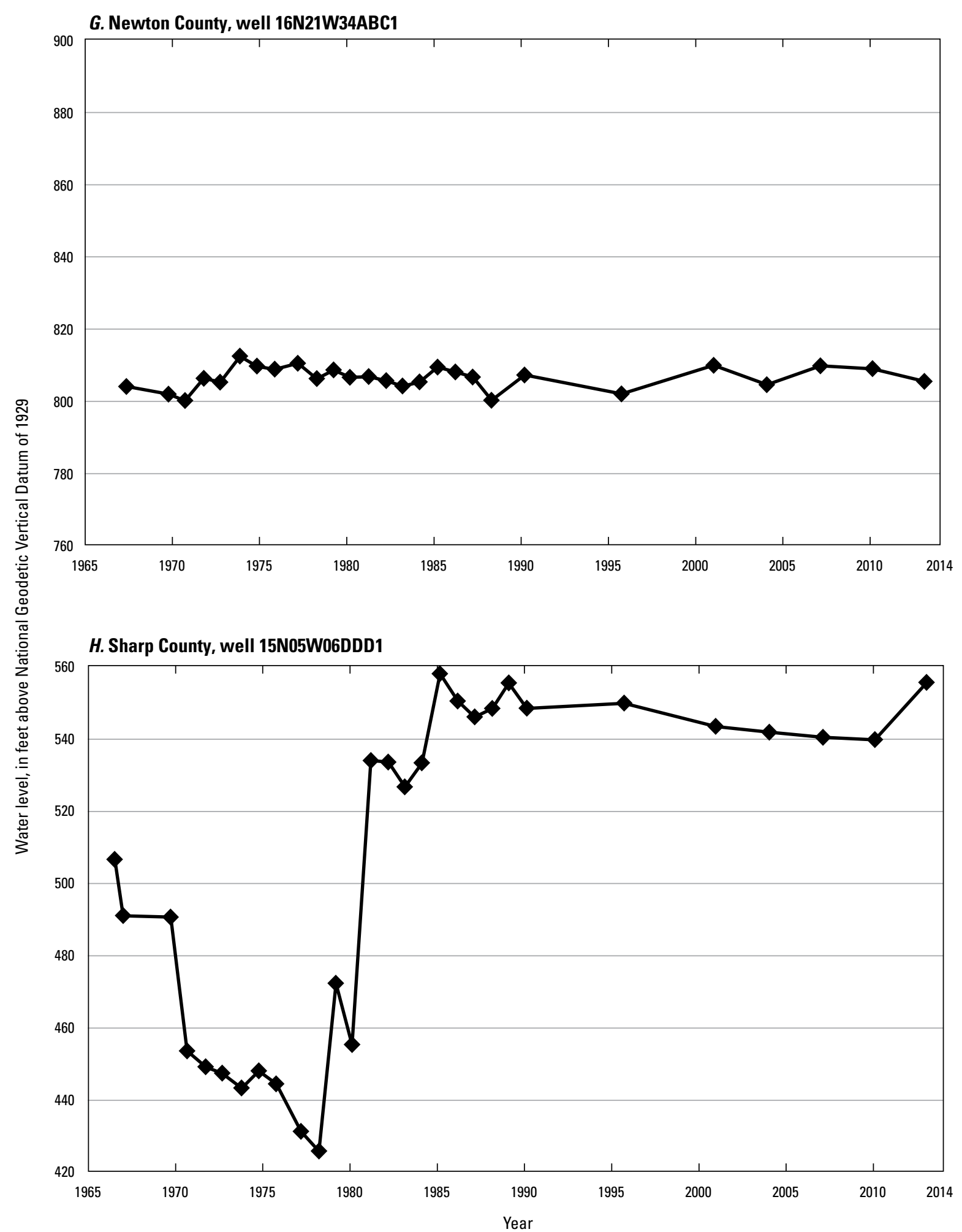

Figure 5. Water-level hydrographs for selected wells completed in the Ozark aquifer in northern Arkansas.-Continued 


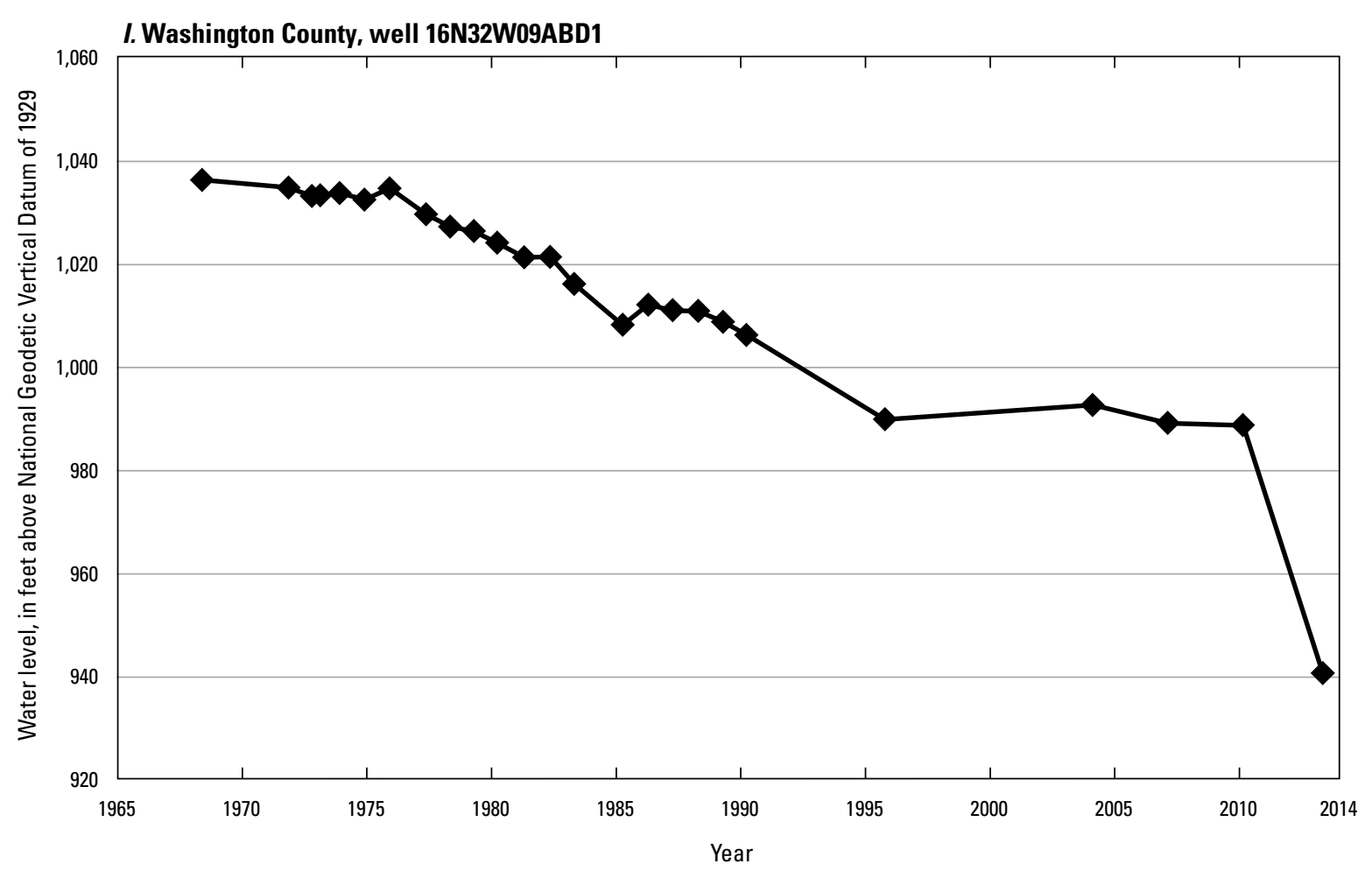

Figure 5. Water-level hydrographs for selected wells completed in the Ozark aquifer in northern Arkansas.-Continued

\section{Summary}

The Ozark aquifer is the largest aquifer, both in area of outcrop and thickness, and the most important source of freshwater in the Ozark Plateaus physiographic province, supplying water to northern Arkansas, southeastern Kansas, southern Missouri, and northeastern Oklahoma. An understanding of the changes and trends in water levels is important for the continued use, planning, and management of this important natural resource.

The study area includes 16 Arkansas counties lying completely or partially within the Ozark Plateaus of the Interior Highlands major physiographic division. The study area is generally bounded on the north by Missouri, on the west by Oklahoma, on the east by the Mississippi Alluvial Plain, and on the south by the Ouachita Province.

The U.S. Geological Survey, in cooperation with the Arkansas Natural Resources Commission and the Arkansas Geological Survey, conducted a study of water levels in the Ozark aquifer within Arkansas. This report presents a potentiometric-surface map of the Ozark aquifer within the Ozark Plateaus of northern Arkansas, representing water-level conditions for the early spring of 2013, and selected waterlevel hydrographs.

Water use from the Ozark aquifer in Arkansas was estimated to be 21.2 million gallons per day. Water use increased about 168 percent from 1965 to 1975 , then decreased about 45 percent from 1975 to 2010 . Water use from the Ozark aquifer declined when some public suppliers converted from a groundwater to a surface-water source and some domestic users connected to a surface-water source for public supplies.

The Ozark Plateaus aquifer system is in, and adjacent to, the Ozark Plateaus and may be divided into five hydrogeologic units based on relative rock permeability and well yields. These units crop out in a concentric pattern centered on and dipping away from the St. Francois Mountains of Missouri. These geohydrologic units consist of rocks that range in age from Cambrian to Mississippian and are the St. Francois aquifer, St. Francois confining unit, Ozark aquifer, Ozark confining unit, and Springfield aquifer. The St. Francois aquifer and St. Francois confining unit underlie the Ozark aquifer. The Ozark confining unit overlies the Ozark aquifer. The Springfield aquifer overlies the Ozark confining unit.

The Ozark aquifer in Arkansas is composed of dolomites, limestones, sandstones, and shales of Late Cambrian to Middle Devonian age and ranges in thickness from approximately 1,100 feet (ft) in the northwestern corner of Arkansas to more than 4,000 ft in the west-central part of Arkansas. Most wells completed in the aquifer yield between 50 and 100 gallons per minute (gal/min), although some wells may yield as much as $600 \mathrm{gal} / \mathrm{min}$. The depth of the Ozark aquifer increases to more than 2,000 $\mathrm{ft}$ in the southern part of the study area. In this area, water quality is affected by increasing amounts of dissolved 
solids, fluoride, sulfide, and radium as water moves downdip, away from recharge areas.

The geohydrology of the Ozark aquifer is complex, consisting of a combination of discrete and discontinuous flow components resulting from spatial variations in regolith thickness, faults, and the presence of chert nodules, lithology, and cementation. Karst topography in the Ozark aquifer consists primarily of limestone and dolomite rocks, which have been dissolved, in places, by groundwater to form caves, sinkholes, and springs. These dissolution features allowed rapid recharge to the aquifer. Hydraulic conductivity ranged from $1 \times 10^{-8}$ feet per second (ft/s) to more than $1 \times 10^{-3} \mathrm{ft} / \mathrm{s}$.

Water-level measurements were made in wells completed in the Ozark aquifer from February to May 2013. The potentiometric-surface map was contoured using the measured water-level data from 42 wells and 6 springs. Hydrographs were constructed for nine wells that had waterlevel measurements with a minimum 20-year period of record. Long-term water-level declines shown in the hydrographs reflect the response of the groundwater-flow system to stresses caused by groundwater pumping Water-level altitudes in wells used to construct the potentiometric-surface map range from about $1,159 \mathrm{ft}$ to $313 \mathrm{ft}$ above the National Geodetic Vertical Datum of 1929 (NGVD 29). The highest water-level altitude of about 1,159 ft above NGVD 29 was in Carroll and Washington Counties. Water-level altitudes of less than $400 \mathrm{ft}$ above NGVD 29 were mapped along the eastern and southeastern part of the study area in Independence, Lawrence, Randolph, and Sharp Counties. The lowest water level of $313 \mathrm{ft}$ above NGVD 29 was measured in southwestern Randolph County.

The direction of groundwater flow generally was affected by local topography in the outcrop area, flowing from high altitudes toward stream valleys. In the eastern part of the study area, southern Baxter, eastern Fulton, Independence, eastern Izard, Lawrence, Randolph, and Sharp Counties, the groundwater flow was generally to the south and southeast. In western Fulton and Izard Counties, the groundwater flow was generally to the southwest. In Boone, Marion, Newton, Searcy, and Stone Counties, the groundwater flow was generally to the east and northeast. In eastern Benton, Carroll, Madison, and eastern Washington Counties, the groundwater flow was generally to the north and northeast. In western Benton and western Washington Counties, the groundwater flow was generally to the west and northwest.

The general level and shape of the potentiometric surface has changed little since predevelopment. A comparison of the predevelopment potentiometric surface and the 2013 potentiometric surface indicates general agreement between the two surfaces with the exception of parts of Boone, Marion, and Washington Counties. In Boone and northern Marion Counties in 2013, water levels declined when compared to the predevelopment potentiometric surface, although the direction of flow was still to the northeast and north. In southern Marion County, water levels declined when compared to the predevelopment, 2007, and 2010 potentiometric surfaces, although the direction of flow was towards and along the stream valleys. The 2007 and 2010 potentiometric surfaces were in agreement with the 2013 potentiometric surface in Boone and northern Marion Counties. In western Benton and northwestern Washington Counties, water levels are similar when compared to the predevelopment potentiometric surface, and the direction of flow was to the west and northwest, similar to the predevelopment direction of flow. The mapped 2007 and 2010 potentiometric surfaces were very different from the mapped 2013 potentiometric surface in western Benton and northwestern Washington Counties. Much of this apparent difference could be because of the differences in hydrologic interpretation in an area with sparse data.

Since 1975, water use has declined 45 percent, while water levels in Boone, Marion, and Washington Counties continued to decline. Localized pumping or other external factors may affect water levels in these areas.

Nine hydrographs were selected as representative of the water-level conditions in their respective counties. Wells in Fulton, Izard, and Newton Counties (station names 20N08W27ABD1, 18N09W15BCB1, and 16N21W34ABC1, respectively) have water levels that were within the usual range of values for their respective counties. Water levels in the wells in Boone, Marion, and Washington Counties (station names 18N19W19BCC1, 19N15W20ACC1, and 16N32W09ABD1, respectively) have water levels that have recently declined or were declining for the period of record. Water levels in the wells in Benton, Carroll, and Sharp Counties (station names 19N29W07DAA1, 21N26W17BCC1, and 15N05W06DDD1, respectively) have water levels that have been rising.

\section{Selected References}

Adamski, J.C., 1996, Nutrients and pesticides in groundwater of the Ozark Plateaus in Arkansas, Kansas, Missouri, and Oklahoma: U.S. Geological Survey Water-Resources Investigations Report 96-4313, 28 p.

Adamski, J.C., Petersen, J.C., Freiwald, D.A., and Davis, J.V., 1995, Environmental and hydrologic setting of the Ozark Plateaus study unit, Arkansas, Kansas, Missouri, and Oklahoma: U.S. Geological Survey Water-Resources Investigations Report 94-4022, 69 p.

Cunningham, W.L., and Schalk, C.W., comps., 2011, Groundwater technical procedures of the U.S. Geological Survey: U.S. Geological Survey Techniques and methods, book 1, chap. A1, $151 \mathrm{p}$.

Czarnecki, J.B., Pugh, A.L., and Blackstock, J.M., 2014, Potentiometric surface of the Ozark aquifer in northern Arkansas, 2010: U.S. Geological Survey Scientific Investigations Report 2014-5013, 16 p., 1 pl. 
Fenneman, N.M., and Johnson, D.W., 1946, Physical divisions of the United States (map): Washington, D.C., U.S. Geological Survey, scale 1:7,000,000.

Halberg, H.N., 1972, Use of water in Arkansas, 1970: Arkansas Geological Commission, Water Resources Summary Number 7, 17 p.

Halberg, H.N., 1977, Use of water in Arkansas, 1975: Arkansas Geological Commission, Water Resources Summary Number 9, 28 p.

Halberg, H.N., and Stephens, J.W., 1966, Use of water in Arkansas, 1965: Arkansas Geological Commission, Water Resources Summary Number 5, 12 p.

Holland, T.W., 1987, Use of water in Arkansas, 1985: Arkansas Geological Commission Water Resources Summary Number 14, 30 p.

Holland, T.W., 1993, Use of water in Arkansas, 1990: U.S. Geological Survey Open-File Report 93-48, pamphlet.

Holland, T.W., 1999, Water use in Arkansas, 1995: U.S. Geological Survey Open-File Report 99-188, 1 sheet.

Holland, T.W., 2004, Estimated water use in Arkansas, 2000: U.S. Geological Survey Scientific Investigations Report 2004-5230, $31 \mathrm{p}$

Holland, T.W., 2007, Water use in Arkansas, 2005: U.S. Geological Survey Scientific Investigations Report 2007$5241,31 \mathrm{p}$.

Holland, T.W., and Ludwig, A.H., 1981, Use of water in Arkansas 1980: Arkansas Geological Commission, Water Resources Summary Number 14, 30 p.

Imes, J.L., 1990, Major geohydrologic units in and adjacent to the Ozark Plateaus Province, Missouri, Arkansas, Kansas, and Oklahoma - Ozark aquifer: U.S. Geological Survey Hydrologic Investigations Atlas HA-711-E, 3 sheets, scale $1: 750,000$.
Imes, J.L., and Emmett, L.F., 1994, Geohydrology of the Ozark Plateaus aquifer system in parts of Missouri, Arkansas, Oklahoma, and Kansas: U.S. Geological Survey Professional Paper 1414-D, 127 p.

Imes, J.L., and Smith, B.J., 1990, Areal extent, stratigraphic relation, and geohydrologic properties of regional geohydrologic units in southern Missouri: U.S. Geological Survey Hydrologic Atlas HA-711-I, 3 sheets, scale $1: 750,000$

Lamonds, A.G., 1972, Water-resources reconnaissance of the Ozark Plateaus Province, northern Arkansas: U.S. Geological Survey Hydrologic Investigations Atlas HA-383, 2 sheets, scale 1:1,000,000.

Mesko, T.O., and Imes, J.L., 1995, Discharge of groundwater along the Ozark Escarpment in southeastern Missouri and northeastern Arkansas: U.S. Geological Survey WaterResources Investigations Report 95-4103, 12 p.

Pugh, A.L., 1998, Potentiometric surface of the Ozark aquifer in northern Arkansas, 1995: U.S. Geological Survey WaterResources Investigation Report 98-4000, 7 p.

Pugh, A.L., 2008, Potentiometric surface of the Ozark aquifer in northern Arkansas, 2007: U.S. Geological Survey Scientific Investigations Report 2008-5137, 16 p.

Schrader, T.P., 2001, Potentiometric surface of the Ozark aquifer in northern Arkansas, 2001: U.S. Geological Survey Water-Resources Investigation Report 01-4233, 11 p.

Schrader, T.P., 2005, Potentiometric surface of the Ozark aquifer in northern Arkansas, 2004: U.S. Geological Survey Water-Resources Investigation Report 2005-5208, 10 p.

White, C.A., 1983, A history of the rectangular survey system: U.S. Department of the Interior, Bureau of Land Management, $774 \mathrm{p}$. 


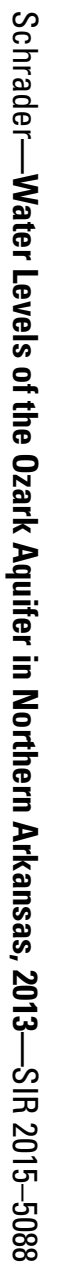

